\title{
PENINGKAT EFEKTIVITAS BERKOMUNIKASI DAN HASIL BELAJAR SISWA KELAS IV PADA PEMBELAJARAN IPA MELALUI MODEL OPEN ENDED DI SDN 26 KAMPUNG AUR KAB PESISIR SELATAN
}

(Improving the Effectiveness of Communication and Learning Outcomes of Class IV Students on IPA Learning through Open Ended Models in SDN 26 Kampung Aur Kab. Pesisir Selatan)

\author{
Oleh: Mira Santika, Gusmaw eti, Zulfa Amrina*) \\ E-mail: mirachantika7@gmail.com
}

*) Dosen FKIP Program Studi Pendidikan Guru Sekolah Dasar Universitas Bung Hatta

\begin{abstract}
The purpose of this study was to describe the increase in the effectiveness of communication and learning outcomes of fourth grade students in learning science through the Open Ended in SDN 26 Kampung Aur, this type of research is a class act, with the subject of the fourth grade students of SDN 26 Kampung Aur, which has 21 students. Research was conducted in the second semester of the school year of 2015/2016, the research instrument used is the effectiveness of communicating student sheets, sheets of assessment of learning outcomes in the cognitive aspects of students at level C1 (knowledge) and C2 (understanding). Based on the research results, the effectiveness of communicating students on the aspects asked in the first cycle obtain an average value of $49.99 \%$ increase in cycle II to $67.45 \%$, the effectiveness of communicating students on aspects of the answer in the first cycle obtain an average value of $53.96 \%$ increased in the second cycle to $71.42 \%$. While the results of student learning at the cognitive level C1 (knowledge) in the first cycle increase in cycle II 68.33 into 80.47, cognitive learning outcomes in level C2 (understanding) in the first cycle increase in cycle II 58.09 to 71.42 , It can be concluded that the Open Ended learning model can increase the effectiveness of communication and student learning outcomes in science teaching fourth grade SDN

26 Kampung Aur.
\end{abstract}

\section{Keywords: Communicating Effectiveness, Results Learning, Model Open Ended, IPA}

\section{PENDAHULUAN}

IPA adalah usaha manusia dalam memahami alam semesta melalui pengamatan yang tepat pada sasaran, serta menggunakan prosedur, dan dijelaskan dengan penalaran sehingga mendapatkan suatu kesimpulan. Dalam hal ini para guru, khususnya yang mengajar sains disekolah. dasar, diharapkan mengetahui dan mengerti hakikat pembelajaran IPA, sehingga dalam pembelajaran IPA guru tidak kesulitan dalam mendesain dan melaksanakan pembelajaran. Siswa yang melakukan pembelajaran juga tidak mendapatkan kesulitan dalam memahami konsep sains.

Berdasarkan wawancara pada tanggal 23 Januari 2016 dengan guru wali kelas IV dengan ibu Gusnita S.Pd tentang mata pembelajaran IPA di SDN 26 Kampung Aur, Kab. Pesisir Selatan di kelas IV dijumpai hasil belajar siswadalam pembelajaran IPA ujian harian pertama semester genap yang rendah. Dari

21 orang siswa kelas IV, 13 orang siswa laki-laki, dan 8 orang siswa perampuan hanya 6 orang yang mendapatkan nilai di atas 69, dan 15 orang mendapatkan nilai dibawah 69 . Berdasarkan nilai kriteria ketuntasan minimal (KKM) yang telah ditentukan sekolah yaitu 69 maka siswa yang mencapai nilai KKM hanya 6 orang. Hal ini disebabkan oleh beberapa faktor, diantaranya siswa kurang aktif dalam berkomunikasi dengan guru saat mengikuti pembelajaran karena guru menggunakan metode ceramah saat belajar dan tidak menggunakan media pembelajaran.

Berkomunikasi secara efektif 
yang dimaksud adalah komunikasi yang mampu menghasilkan perubahan sikap seseorang, saling bertukar pendapat, dan mengeluarkan ide, sehingga guru dengan siswa saling bertukar pendapat serta mengeluarkan ide. Begitupun dengan siswa, jika komunikasi siswa dengan guru itu efektif maka hasil belajar siswa berkemungkinan meningkat. Jadi, pemahaman dan pengetahuan siswa dalam belajar juga akan meningkat serta menghasilkan hasil belajar yang efektif (berhasil).

Berdasarkan data nilai UH Semester II kelas IV SDN 26 Kampung Aur, Kab. Pesisir Selatan, Kec. Batang Kapas tahun ajaran 2015/2016 menunjukkan bahwa nilai UH siswa Semester II pada pembelajaran IPA sangat rendah.

Model Pembelajaran open ended merupakan proses pembelajaran yang didalamnya tujuan dan keinginan individu/siswa dibangun dan dicapai secara terbuka (Huda, 2014:279). Dalam menentukan masalah yang akan dijadikan landasan pembelajaran, Ngalimun (Istarani, 2015:106) mengatakan bahwa "sajian masalah haruslah konstektual, kaya makna secara matematik (gunakan gambar, diagram, tabel), kembangkan permasalahan sesuai dengan kemampuan berpikir siswa, kaitkan dengan materi selanjutnya, siapkan rencana bimbingan (sedikit demi sedikit dilepas mandiri)".

Menurut Miarso (Istarani,

2015:119) bahwa pembelajaran yang efektif adalah yang menghasilkan belajar yang bermanfaat dan bertujuan bagi siswa, melalui pemakaian prosedur yang tepat. Sedangkan Sanjaya (Istarani, 2015:119) mengatakan bahwa: efektivitas berhubungan dengan tingkat keberhasilan pelaksanaan pembelajaran yang di desain oleh guru untuk mencapai tujuan pembelajaran, baik tujuan dalam skala yang sempit tujuan pembelajaran khusus, maupun tujuan dalam skala yang lebih luas, seperti tujuan kurikuler, tujuan institusional dan bahkan tujuan nasional.

Menurut Nawawi dalam K.Brahim
(Susanto, 2012:5), hasil belajar dapat diartikan sebagai tingkat keberhasilan siswa dalam mempelajari materi pelajaran di sekolah yang dinyatakan dalam skor yang diperoleh dari hasil tes mengenal sejumlah materi pelajaran tertentu. Menurut Sunal (dalam Drs.Ahmad Susanto, 2012:5), evaluasi merupakan proses penggunaan informasi untuk membuat pertimbangan seberapa efektif suatu program telah memenuhi kebutuhan siswa. dapat mengasah kemampuan berpikir logis siswa yang berdampak pada meningkatnya hasil belajar siswa. Dalam model ini, siswa diberi kesempatan untuk membangun kesan mengenai konsep yang sedang dipelajari dengan mengkaitkan dengan pengalaman sehari-hari, kemudian siswa diberikan kesempatan untuk mengemukakan ide mereka mengenai konsep yang dipelajari, lalu guru meminta siswa membandingkan pendapatnya dengan pendapat siswa lain dan mengemukakan keunggulan dari pendapat mereka tentang konsep yang dipelajari, selanjutnya guru mengusulkan peragaan demonstrasi untuk menguji kebenaran pendapat siswa, lalu siswa diberi kesempatan untuk menguji ide alternatif yang mereka bangun untuk menyelesaikan persoalan yang bervariasi, dan selanjutnya siswa diberi kesempatan mengevaluasi kelemahan dari konsepnya yang lama.

Hasil belajar dapat diartikan sebagai perubahan-perubahan yang terjadi pada diri siswa, baik yang menyangkut aspek kognitif, afektif, dan psikomor sebagai hasil dari kegiatan belajar. Menurut Nawawi dalam Susanto (2012:5) "hasil belajar dapat diartikan sebagai tingkat keberhasilan siswa dalam mempelajari materi pelajaran di sekolah yang dinyatakan dalam skor yang diperoleh dari hasil tes mengenal sejumlah materi pelajaran tertentu". 


\section{METODE PENELITIAN}

Jenis penelitian ini adalah penelitian tindakan kelas (classroom research) dengan tahapan-tahapan pelaksana meliputi perencanaan, tindak pelaksanaan, tindak pelaksanaan, observasi dan evaluasi/refleksi. Lokasi penelitian ini di SDN 26 Kampung Aur,Kab. Pesisir Selatan, Kec. Batang Kapas dengan 21 orang siswa kelas IV yang terdiri dari 13 orang siswa laki- laki dan 8 orang siswa perempuan pada semester II tahun ajaran 2015/2016

\section{HASIL PENELITIAN}

Penelitian ini dilakukan di SDN 26 Kampung Aur Kecamatan Batang Kapas Kabupaten Pesisir Selatan, dengan subjek penelitian adalah siswa kelas IV yang berjumlah 21 orang yang terdiri dari 13 orang siswa lakilaki dan 8 orang siswa perempuan. Pada bab ini dikemukakanh hasil penelitian peningkatan efektivitas berkomunikasi dan hasil belajar siswa kelas IV pada pembelajaran IPA melalui model open ended pada semester II tahun ajaran 2015/2016. Dalam pelaksanaan tindakan penelitian, peneliti bertindak sebagai guru kelas IV dan dibantu oleh 2 orang observer, yaitu observer I Ibu Gusnita, S.Pd (Guru kelas IV) dan observer II Ibu Lira, S.Pd (Salah satu guru di SDN 26 Kampung Aur).

\section{a. Data Kegiatan Guru}

Berdasarkan lembar observasi
aktivitas guru dalam mengelola
pembelajaran pada siklus I, maka jumlah
skor dan persentase aktivitas guru dalam
mengelola pembelajaran pada siklus I dapat
dilihat pada Tabel 1 berikut:

Tabel 1: Persentase Aktivitas Guru pada Siklus I

\begin{tabular}{|c|c|c|}
\hline Pertemuan & $\begin{array}{l}\text { Jumlah } \\
\text { Skor }\end{array}$ & Persentase \\
\hline 1 & 11 & $61,11 \%$ \\
\hline 2 & 14 & $77,78 \%$ \\
\hline Rata-Rata & & $69,45 \%$ \\
\hline
\end{tabular}
persentase $69,45 \%$, sehingga sudah dapat dikatakan cukup baik tetapi belum maksimal.

Berdasarkan lembar observasi aktivitas guru dalam mengelola pembelajaran pada siklus II, maka jumlah skor dan persentase aktivitas guru dalam mengelola pembelajaran pada siklus II dapat dilihat pada Tabel 2 berikut:

Tabel 2: Persentase Aktivitas Guru pada Siklus II

\begin{tabular}{|c|c|c|}
\hline Pertemuan & $\begin{array}{l}\text { Jumlah } \\
\text { Skor }\end{array}$ & Persentase \\
\hline 1 & 14 & $77,78 \%$ \\
\hline 2 & 16 & $88,89 \%$ \\
\hline Rata-Rata & & $83,35 \%$ \\
\hline
\end{tabular}

memperoleh nilai rata-rata persentase $83,35 \%$, sehingga sudah dapat dikatakan sangat baik, karena guru telah melakukan langkah-langkah pembelajaran IPA dengan menggunakan model open ended dengan sangat baik.

\section{b. Data Efektivitas Berkomunikasi Siswa}

Berdasarkan lembar observasi efektivitas berkomunikasi siswa dalam mengelola pembelajaran pada siklus I, maka jumlah skor dan nilai rata- rata efektivitas berkomunikasi siswa dalam melaksanakan pembelajaran pada siklus I dapat dilihat pada Tabel 3 berikut:

Tabel 3: Nilai Rata-rata Efektivitas Berkomunikasi Siswa pada aspek bertanya pada Siklus I

\begin{tabular}{|c|c|c|}
\hline Pertemuan & $\begin{array}{l}\text { Jumlah } \\
\text { Skor }\end{array}$ & $\begin{array}{l}\text { Rata-rata } \\
\text { Persentase }\end{array}$ \\
\hline 1 & 26 & $41,26 \%$ \\
\hline 2 & 37 & $58,73 \%$ \\
\hline Rata-Rata & & $49,99 \%$ \\
\hline
\end{tabular}

bahwa nilai rata-rata efektivitas berkomunikasi siswa dalam aspek bertanya memperoleh nilai rata-rata sebesar 49,99\% sehingga dikatakan kurang efektif. 
Berdasarkan lembar observasi efektivitas berkomunikasi siswa dalam melaksanakan pembelajaran pada siklus II, maka jumlah skor dan nilai rata-rata efektivitas berkomunikasi siswa dalam melaksanakan pembelajaran pada siklus II dapat dilihat pada Tabel 4 berikut:

Tabel 4: Nilai Rata-rata Persentase Efektivitas Berkomunikasi Siswa pada aspek bertanya pada Siklus II

\begin{tabular}{lll}
\hline Pertemuan & $\begin{array}{l}\text { Jumlah } \\
\text { Skor }\end{array}$ & $\begin{array}{l}\text { Rata-rata } \\
\text { Persentase }\end{array}$ \\
\hline 1 & 38 & $60,31 \%$ \\
\hline 2 & 48 & $74,60 \%$ \\
\hline Rata-Rata & & $67,45 \%$ \\
\hline
\end{tabular}

Dari Tabel 4 di atas dapat dilihat nilai rata-rata efektivitas berkomunikasi siswa dalam aspek bertanya memperoleh nilai ratarata $67,45 \%$ sehingga sudah dapat dikatakan cukup efektif karena pada saat siswa mengikuti pembelajaran, sudah dapat dilihat meningkatnya efektivitas bertanya siswa pada pembelajaran IPA dengan menggunakan model open ended. Sedangkan nilai rata-rata efektivitas berkomunikasi siswa pada aspek menjawab dalam pembelajaran IPA dengan menggunakan model open ended pada siklus II dapat dilihat pada table 5 dibawah ini.

Tabel 5: Nilai rata-rata Efektivitas Berkomunikasi Siswa pada aspek menjawab pada Siklus II

\begin{tabular}{lll}
\hline Pertemuan & $\begin{array}{l}\text { Jumlah } \\
\text { Skor }\end{array}$ & $\begin{array}{l}\text { Rata-rata } \\
\text { Persentase }\end{array}$ \\
\hline 1 & 41 & $65,07 \%$ \\
\hline 2 & 49 & $77,77 \%$ \\
\hline Rata-Rata & & $71,42 \%$ \\
\hline
\end{tabular}

Dari Tabel 5 di atas dapat dilihat nilai rata-rata efektivitas berkomunikasi siswa dalam aspek menjawab memperoleh nilai rata-rata $71,42 \%$ sehingga dapat dikatakan cukup efektif.

\section{c. Data Hasil Belajar Siswa}

Berdasarkan lembar penilaian hasil belajar kawasan kognitif C1 (pengetahuan) dan C2 (pemahaman) siswa pada siklus II, maka jumlah skor dan persentase hasil belajar kawasan kognitif siswa pada siklus II dapat dilihat pada Tabel 6 berikut

Tabel 6: Persentase Hasil Belajar Kawasan Kognitif dalam aspek C1 (pengetahuan) dan C2 (pemahaman) Siswa Kelas IV pada Siklus II

\begin{tabular}{lcc}
\hline Siklus II & $\begin{array}{l}\text { Jumlah } \\
\text { Skor }\end{array}$ & Persentase \\
\hline $\begin{array}{l}\text { C1 } \\
\text { (pengetahuan) }\end{array}$ & 1690 & $100 \%$ \\
\hline $\begin{array}{l}\text { C2 } \\
\text { (pemahaman) }\end{array}$ & 1500 & $66,67 \%$ \\
\hline Rata-Rata & & $83,33 \%$ \\
\hline \multicolumn{1}{c}{ Dari Tabel 6 di atas dapat }
\end{tabular}

dilihat bahwa persentase hasil belajar kognitif pada tingkat $\mathrm{C} 1$ (pengetahuan) dan C2 (pemahaman) siswa memiliki rata-rata $83,33 \%$ sehingga sudah dapat dikatakan sangat baik dan maksimal. Pada saat diskusi berlangsung siswa sudah disiplin, mengumpulkan tugas tepat waktu, tidak berbicara saat diskusi, dan patuh terhadap perintah guru. Target ketuntasan belajar yang telah ditetapkan oleh peneliti pada indikator keberhasilan ketuntasan hasil belajar pada aspek kognitif tingkat $\mathrm{C} 1$ (pengetahuan) dan $\mathrm{C} 2$ (pemahaman) yaitu70\% dari jumlah siswa. Pada siklus II ini, hasil belajar aspek kognitif tingkat $\mathrm{C} 1$ (pengetahuan) dan C2 (pemahaman) mencapai target, yaitu $83,33 \%$. Ketercapaian ketuntusan belajar pada siklus II ini sudah mencapai target ketuntasan belajar.

\section{PEMBAHASAN}

Penelitian tindakan kelas ini terdiri dari dua siklus yang setiap siklusnya terdiri dari dua kali pertemuan. Sehubungan dengan jadwal mata pelajaran IPA di kelas IV SDN 26 Kampung Aur Kab. Pesisir Selatan 2 jam pelajaran dalam 1 minggu, maka kegiatan tes akhir siklus peneliti lakukan pada 1 jam pelajaran terakhir di pertemuan kedua tiap siklus. Penelitian ini menggunakan instrumen penelitian berupa lembar aktivitas guru, lembar efektivitas berkomunikasi siswa, tes hasil belajar siswa, dan dokumentasi.

Pembelajaran menggunakan model pembelajaran open ended 
merupakan hal yang baru bagi siswa. Kegiatan belajar dengan model pembelajaran open ended ini bersumber pada perpaduan pengetahuan-pengetahuan yang dimiliki siswa tentang materi yang dipelajari, sehingga pembelajaran lebih abstrak dan dapat dipahami siswa dengan baik, mengingat kriteria siswa pada usia sekolah dasar yang bersifat operasional konkret. Pembelajaran dengan menggunakan model pembelajaran open ended ini juga mengajarkan siswa untuk memberi respon tentang masalah apa yang ditemukan siswa dalam belajar. Yang mana salah satu tahap model pembelajaran open ended ini adalah mencatat respon dari siswa dari hasil temuanya. Pada tahap ini, guru harus mencatat respon dari siswa dan menyuruh siswa menyampaikan hasil temuan atau diskusinya. Kemudian dengan menggunakan model pembelajaran open ended, siswa dapat memecahkan masalah yang disajikan oleh guru dan menyampaikan hasil temuanya.

\section{KESIMPULAN}

a. Pada lembar efektivitas berkomunikasi bertanya pada siklus I sebesar 49,99\% dan pada siklus II meningkat sebesar $67,45 \%$. Sedangkan pada efektivitas berkomunikasi menjawab siswa nilai rata-rata pada siklus I sebesar 53,96\% dan pada siklus II meningkat sebesar $71,42 \%$. Jadi efektivitas berkomunikasi bertanya dan menjawab siswa dapat meningkat pada siklus II dengan model pembelajaran Open Ended.

b. Hasil belajar siswa pada kognitif di tingkat pengetahuan (C1) dapat memperoleh nilai rata-rata siklus I sebesar $68,33 \%$ dan pada siklus II meningkat sebesar $80,47 \%$. Sedangkan tingkat pemahaman (C2) pada pembelajaran IPA dengan model Open Ended dapat memperoleh nilai rata-rata siklus I sebesar 58,09\% dan pada siklus II meningkat sebesar $71,42 \%$. Jadi dengan model open ended dapat meningkatkan hasil belajar siswa pada pembelajaran IPA.

\section{SARAN}

a. Bagi siswa, pada efektivitas berkomunikasi pada aspek bertanya dan menjawab harus dapat ditingkatkan karena aspek bertanya dan menjawab sangat berpengaruh terhadap kemampuan siswa dalam memahami pembelajaran sehingga dapat meningkatkan hasil belajar siswa.

b. Bagi guru, pelaksanaan pembelajaran dengan menggunakan model open ened dapat menjadi salah satu alternatif dalam pelaksanaan pembelajaran. Dalam menggunakan model open ened, motivasi dari guru serta efektivitas dari siswa sangat dibutuhkan untuk memancing pengetahuan siswa karena model open ened ini berpusat pada pengetahuan yang dimiliki siswa.

c. Bagi sekolah, diharapkan dapat menambah pengetahuan dan inovasi terhadap pembaharuan dalam proses pembelajaran. d. Bagi peneliti, diharapkan dapat menambah wawasan, pengetahuan, dan pengalaman bagi peneliti sebagai bekal untuk mengajar di SD dan bagi peneliti lain yang ingin menerapkan model open ened ini diharapkan dapat dijadikan motivasi.

\section{DAFTAR PUSTAKA}

Akbar. 2013. Instrumen Perangkat Pembelajaran. PT Remaja Rosdakarya.

Arikunto, Suharsimi, dkk. 2012. Penelitian Tindakan Kelas. Jakarta: Bumi Aksara.

Desfitri, Rita dkk. 2008. Laporan Pengembangan Inovasi Pembelajaran di Sekolah (PIPS). Jurnal. FKIP. Universitas Bung Hatta.

Istarani.2011. 58 Model Pembelajaran 
Inovatif. Medan, Media Persada

Istarani.2015. Ensiklopedi Pendidikan. Media

Persada Pembelajaran. Yogyakarta

Huda. 2014. Model-model Pengajaran dan eJournal Ilmu Komunikasi, 2014, 2 (4):287-296. ISSN 0000-0000, http://ejournal.ilkom.fisipunmul.ac.id/site Copyright 2014

Sudjana.2012. Penilaian Hasil Belajar Proses Belajar Mengajar. Bandung

Sumantri. 2002. Metode Penelitian. Jakarta: Bina Ilmu

Susanto. 2014. Teori Belajar dan Pembelajaran. Jakarta 
